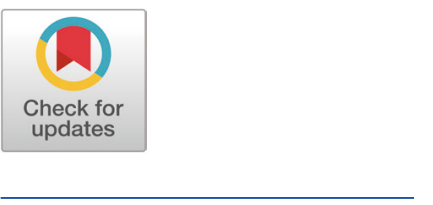

Received: Feb 19, 2020

Revised: May 31, 2020

Accepted: Jun 2, 2020

${ }^{*}$ Corresponding author Chang-Hyun Kim

School of Animal Life Convergence

Science, Hankyong National University,

Anseong 17579, Korea.

Tel: +82-31-670-5095

E-mail: kimch@hknu.ac.kr

Copyright $\odot 2020$ Korean Society of

Animal Sciences and Technology.

This is an Open Access article

distributed under the terms of the

Creative Commons Attribution

Non-Commercial License (http://

creativecommons.org/licenses/by-

$\mathrm{nc} / 4.0 /$ ) which permits unrestricted

non-commercial use, distribution, and reproduction in any medium, provided

the original work is properly cited.

ORCID

Joong Kook Park

https://orcid.org/0000-0002-9959-0578

Joon-Mo Yeo

https://orcid.org/0000-0002-1617-2195

Gui-Seck Bae

https://orcid.org/0000-0003-4006-1871

Eun Joong Kim

https://orcid.org/0000-0002-5962-6994

Chang-Hyun Kim

https://orcid.org/0000-0001-6325-9755

Competing interests

No potential conflict of interest relevant

to this article was reported.

\section{Effects of supplementing limiting amino acids on milk production in dairy cows consuming a corn grain and soybean meal-based diet}

\author{
Joong Kook Park', Joon-Mo Yeo ${ }^{2}$, Gui-Seck Bae ${ }^{3}$, Eun Joong Kim ${ }^{4}$ \\ and Chang-Hyun $\mathrm{Kim}^{1 *}$
}

${ }^{1}$ School of Animal Life Convergence Science, Hankyong National University, Anseong 17579, Korea
${ }^{2}$ Department of Dairy Science, Korean National College of Agriculture and Fisheries, Jeonju 54874, Korea
${ }^{3}$ Department of Animal Science and Technology, Chung-Ang University, Anseong 17546, Korea
${ }^{4}$ Department of Animal Science, Kyungpook National University, Sangju 37224, Korea

\section{Abstract}

Limiting amino acids (AAs) for milk production in dairy cows fed on a concentrate diet of corn grain and soybean meal was evaluated in this study. Four lactating and multiparous Holstein cows (in third or fourth parities, with an average body weight of $633 \pm 49.2 \mathrm{~kg}$ ), 8 to 9 weeks into their lactation period, were used in a $4 \times 4$ Latin square design. The experiment comprised four dietary treatments: (1) no intravenous infusion (control); (2) control plus intravenous infusion of an AA mixture of $6 \mathrm{~g} / \mathrm{d}$ methionine, $19.1 \mathrm{~g} / \mathrm{d}$ lysine, $13.8 \mathrm{~g} / \mathrm{d}$ isoleucine, and $15.4 \mathrm{~g} / \mathrm{d}$ valine (4AA); (3) control plus intravenous infusion of the AA mixture without methionine (no-Met); and (4) control plus intravenous infusion of the AA mixture without lysine (no-Lys). All animals were fed on a controlled diet $(1 \mathrm{~kg} / \mathrm{d}$ alfalfa hay, $10 \mathrm{~kg} / \mathrm{d}$ silage, $14 \mathrm{~kg} / \mathrm{d}$ concentrate mixture, ad libitum timothy hay). The AA composition of the diet and blood were determined using an automatic AA analyzer. Milk composition (protein, fat, lactose, urea nitrogen, and somatic cell counts) was determined using a MilkoScan. The results showed that feed intake for milk production did not differ from that of intravenous infusion using a limiting AA mixture. The 4AA treatment numerically had the highest milk yield $(32.4 \mathrm{~kg} / \mathrm{d})$, although there was no difference when compared with the control $(31.2 \mathrm{~kg} / \mathrm{d})$, no-Met $(31.3 \mathrm{~kg} / \mathrm{d})$, and no-Lys $(31.7 \mathrm{~kg} / \mathrm{d})$ treatments. The concentration of AAs in blood plasma of cows in all treatments, mainly isoleucine and valine, increased significantly compared with that of control. The no-Met treatment increased $(p<0.05)$ the concentration of lysine in the blood relative to the control and no-Lys treatments, whereas the no-Lys treatment increased $(p<0.05)$ the concentration of methionine relative to the control and no-Met treatments. In conclusion, milk production increased when feeding $10 \mathrm{~g} / \mathrm{d}$ methionine to the cows, together with their concentrate diet of corn grain and soybean meal.

Keywords: Limiting amino acid, Methionine, Lysine, Dairy cow 
Funding sources

This work was supported by Korea Institute of Planning and Evaluation for Technology in Food, Agriculture, Forestry and Fisheries (IPET) through Agri-Bio Industry Technology Development Program, funded by Ministry of Agriculture, Food and Rural Affairs (11807303).

Acknowledgements Not applicable.

\begin{abstract}
Availability of data and material Upon reasonable request, the datasets of this study can be available from the corresponding author.
\end{abstract}

\section{Authors' contributions}

Conceptualization: Park JK, Kim CH.

Data curation: Park JK, Kim CH.

Formal analysis: Park JK.

Methodology: Park JK, Kim CH.

Software: Park JK, Bae GS.

Validation: Yeo JM, Kim CH.

Investigation: Park JK, Yeo JM, Bae GS, Kim EJ, $\mathrm{Kim} \mathrm{CH}$.

Writing - original draft: Park JK, Kim EJ, Kim CH. Writing - review \& editing: Park JK, Yeo JM,

Bae GS, Kim EJ, Kim CH.

Ethics approval and consent to participate The protocol and the standard operating procedures of this study were reviewed and approved by the National Institute of Animal Science's Institutional Animal Care and Use Committee (No. 2010-066, C-grade).

\section{INTRODUCTION}

The efficiency of nutrient utilization of the dairy cow is relatively low compared with monogastric animals, and this is particularly so with absorbed nitrogen $(\mathrm{N})$ in the form of amino acids (AAs). Therefore, efforts have been made to balance AAs in the diet of dairy cows to produce more milk and milk protein. These efforts have been increased due to the demand from environmental sectors, highlighting the environmental impact of the ruminant industry on the planet [1]. Further efforts have been focused on reducing this environmental impact by reducing $\mathrm{N}$ excretion. In developed countries, several studies have been conducted on limiting AAs and their effects on milk production in dairy cows. The French National Institute for Agricultural Research (INRA) has conducted research to establish the requirements of methionine and lysine [2,3]. In the United States, the requirements of essential AAs were established through modeling in the Cornell Net Carbohydrate and Protein System (CNCPS) [4,5], at Cornell University, and by the National Research Council (NRC) [6].

Methionine [3,7] and lysine [8,9] are widely known as first-limiting AAs, which affect the milk production and milk protein of dairy cows under many dietary regimes. In addition, lysine and methionine have long been regarded as potentially rate-limiting factors for milk production, either alone or in combination [6,10-12]. The production responses to dairy cows can be greater when methionine, used in combination with lysine, is directed into the small intestine and bloodstream $[13,14]$. In various experimental diets, differences in the response to supplemented AAs are likely to be caused by variations in the quantity and proportion of AAs in the microbial and dietary protein that are digested and absorbed by the small intestine. The inconsistency in the response to supplemental methionine and lysine may indicate that these are not always clearly first-limiting. The first-limiting AA for milk production was reported to be histidine from a grass silage diet $[15,16]$. Therefore, although methionine and lysine are known as the first-limiting AA in the milk production of dairy cows under many dietary regimes, these AAs may not be the first-limiting AAs in all feeding conditions $[17,18]$. In Korea, dairy cows are typically fed a high level of concentrate diets, containing a large quantity of corn grain and soybean meal [19]. With methionine and lysine, often isoleucine and valine may be limiting AAs, and these AAs may also be insufficient for milk production in a diet of dairy cows that contains corn grain and soybean meal. However, there have been limited studies on the requirements and efficiency of AA use in the metabolic protein of dairy cows. This study aimed to investigate the effects of first-limiting AAs of dairy cows fed concentrate diet containing corn grain and soybean meal.

\section{MATERIALS AND METHODS}

The protocol and the standard operating procedures of this study were reviewed and approved by the Institutional Animal Care and Use Committee of the National Institute of Animal Science, Korea (No. 2010-066, C-grade).

\section{Animals, experimental treatments, and design}

This study employed four lactating multiparous Holstein dairy cows in third or fourth parities with a similar dairy performance and was conducted at an experimental farm at the National Institute of Animal Science located in Cheonan-si, Korea. The cows, with an average body weight of $633 \pm 49.2$ $\mathrm{kg}$, were 8 to 9 weeks into their lactation period at the beginning of the experiment. The animals were individually housed in metabolism stalls that were installed with floor mattresses to minimize foot problems and stress and were milked twice a day at 06:00 and 18:00. The cows received a 14 
$\mathrm{kg} / \mathrm{d}$ concentrate mixture (63.0\% ground corn, 20.0\% soybean meal, $9.4 \%$ cottonseed meal, $6.0 \%$ sugar beet pulp and $1.6 \%$ mineral and vitamin mixture on a dry matter basis), $10 \mathrm{~kg} / \mathrm{d}$ of corn silage, and $1 \mathrm{~kg} / \mathrm{d}$ of alfalfa hay on a fresh weight basis. They were also given access, ad libitum, to timothy hay. The diet was formulated to supply the cows with metabolizable energy and metabolizable protein in excess of their normal requirements [6]. Feed was given equally in the two daily feedings after milking. Dry matter intakes were measured daily by weighing the amount of feed offered. The refusal was removed from the feed bin at 07:00 in the morning prior to the next feeding. The dry matter content of the feed was determined once every other week for concentrates and timothy. Then, dry matter intake was calculated as the difference between the amounts offered and refused in terms of dry matter. The amount of timothy hay offered was adjusted to ensure that there was refusal of up to $15 \%$. The chemical composition and AA content of the basal diets are presented in Tables 1 and 2 .

Table 1. Chemical composition (\% of dry matter unless otherwise stated) of concentrate, corn silage, alfalfa hay and timothy hay used in the experiments

\begin{tabular}{lcccc}
\hline \multicolumn{1}{c}{ Item } & Concentrate $^{\text {1) }}$ & Corn silage & Alfalfa hay & Timothy hay \\
\hline Dry matter & 86.7 & 24.7 & 89.9 & 89.5 \\
Crude protein & 22.4 & 8.0 & 15.2 & 6.4 \\
Ether extract & 2.2 & 2.5 & 1.2 & 1.2 \\
Crude ash & 4.4 & 3.9 & 9.4 & 4.9 \\
Neutral detergent fiber & 24.1 & 53.9 & 55.5 & 71.5 \\
Acid detergent fiber & 8.4 & 34.4 & 42.5 & 41.1
\end{tabular}

${ }^{1)}$ Contained corn grain $63.0 \%$, soybean meal $20.0 \%$, cottonseed meal $9.4 \%$, sugar beet pulp $6.0 \%$, mineral $0.7 \%$, and vitamin mixture $0.9 \%$

Table 2. Amino acid (AA) profiles (\% of crude protein) of concentrate, corn silage, alfalfa hay and timothy hay used in the experiment

\begin{tabular}{lcccc}
\hline \multicolumn{1}{c}{ Item } & Concentrate & Corn silage & Alfalfa hay & Timothy hay \\
\hline Essential AA & & & & \\
Arginine & 5.83 & 3.32 & 3.42 & 3.70 \\
Histidine & 3.16 & 1.74 & 2.84 & 2.69 \\
Isoleucine & 3.23 & 3.06 & 3.34 & 3.02 \\
Leucine & 8.85 & 8.24 & 6.69 & 6.16 \\
Lysine & 5.01 & 2.60 & 5.69 & 6.18 \\
Methionine & 0.88 & 2.54 & 1.23 & 1.41 \\
Phenylalanine & 5.05 & 4.09 & 4.57 & 4.59 \\
Threonine & 3.67 & 3.48 & 4.37 & 3.98 \\
Valine & 3.82 & 4.16 & 4.33 & 4.15 \\
Non-essential AA & & & & \\
Alanine & 5.18 & 10.72 & 5.02 & 5.43 \\
Aspartic acid & 9.13 & 4.77 & 12.53 & 10.31 \\
Cysteine & 0.80 & 2.97 & 1.31 & 1.59 \\
Glycine & 3.90 & 4.29 & 4.43 & 4.26 \\
Glutamic acid & 19.76 & 9.37 & 9.70 & 9.48 \\
Proline & 6.36 & 6.09 & 9.37 & 10.02 \\
Serine & 5.01 & 2.85 & 4.90 & 4.31 \\
Tyrosine & 3.57 & 1.58 & 2.73 & 2.51 \\
\hline
\end{tabular}


All animals received the basal diet for at least 21 days before the start of the experiment. The four experimental treatments were (1) the basal diet as described above (control); (2) control with a continuous intravenous infusion of the AA mixture of $6 \mathrm{~g} / \mathrm{d}$ methionine, $19.1 \mathrm{~g} / \mathrm{d}$ lysine, $13.8 \mathrm{~g} /$ $\mathrm{d}$ isoleucine, and $15.4 \mathrm{~g} / \mathrm{d}$ valine (4AA); (3) control with an infusion of the AA mixture, without methionine (no-Met); and (4) control with the infusion of the AA mixture, without lysine (no-Lys). The total experimental period was 60 days (including 21 days of basal diet feeding). The amounts of four amino acids infused were calculated approximate difference between the amounts absorbed from the basal diet and the amounts contained in milk protein according to NRC [6]. The study employed a $4 \times 4$ Latin square design, and each period lasted 10 days. A solution of AA (pharmaceutical grade; Forum Chemicals, Redhill, UK) for intravenous infusion was prepared by gradually adding a daily dose of the AA to distilled water. The $\mathrm{pH}$ was adjusted to 7.4, and the volume made up to four liters. All solutions were filtered through a Whatman cellulose nitrate membrane filter (pore size $0.45 \mu \mathrm{m}$; Whatman International, Maidstone, UK) and autoclaved at $121^{\circ} \mathrm{C}$ for $15 \mathrm{~min}$. The solution of AA in a volume of $4 \mathrm{~L} / \mathrm{d}$ was infused into the jugular vein. The infusion rate was set to deliver the required volume within a $23 \mathrm{~h}$ period, and the solution was changed at 09:00 each day. An indwelling polyethylene catheter (Arrow International, Reading, MA, USA) was inserted into the jugular vein approximately $24 \mathrm{~h}$ before the start of infusion. The area around the entry point of the catheter was protected with an adhesive bandage, which was changed every 2 days. The catheter was changed at the end of each experimental period and was flushed with sterile citrate saline before the start of each day's infusion to allow the infusates to flow freely. No infusion was given to the control in the experiment. The dosage sets of the AA solution were replaced every period.

The body weight of the cows was measured, using an electric scale, for 2 days prior to the experiments. Feed intake and milk yield were recorded daily. The milk composition was determined using a representative, composite sample from the previous four consecutive milkings. Samples of blood were taken from the vein of the tail muscle area of the cows using a heparin-treated $10 \mathrm{~mL}$ vacutainer $^{\circledR}$ tubes (BD, Texarkana, TX, USA) on the last day of each experimental period. The blood samples were centrifuged (VS-6000CFi, Vision Scientific, Seoul, Korea) immediately to separate the plasma, which was then stored at $-20^{\circ} \mathrm{C}$, pending further analysis. No evidence of hemolysis was found.

\section{Chemical analysis}

Feed samples were taken, dried in a forced-air oven at $60^{\circ} \mathrm{C}$, ground to pass through a $1 \mathrm{~mm}$ screen, and analyzed for chemical composition using the appropriate AOAC [20] and Van Soest methods [21]. Milk samples were analyzed for milk protein, milk fat, lactose, milk urea-N (MUN), and somatic cell numbers with a Milkoscan 4000 series (Foss Electric, Hillerød, Denmark). For the AA in the feed samples collected on the first day of each experimental period, $6 \mathrm{~N} \mathrm{HCl}$ was added to the feed for hydrolysis, the $\mathrm{HCl}$ was then immediately removed through drying, using a concentrator (V805, BÜCHI, Flawil, Switzerland), and the dried materials were dissolved with a buffer solution and then analyzed with an AA analyzer (Beckman 6300, Beckman Coulter, Brea, CA, USA). For plasma AA, the plasma samples were mixed with 8\% 5-sulfosalicylic acid (No. 2130, Sigma-A1drich, St. Louis, MO, USA) at a 1:1 ratio and centrifuged. The retrieved supernatants were filtered using a membrane filter with a $0.2 \mu \mathrm{m}$ pore size and then analyzed with an automatic AA analyzer (Biochrom 20, Biochrom, Cambridge, UK).

\section{Statistical analyses}

The mean values of feed intake, milk yield, and milk compositions were recorded for the last 7 days of each experimental period, and AA in the blood and body weight were measured for the last 2 
days of each experimental period. The results were subjected to the analysis of variance using GenStat 5 [22], and the least significant difference values were calculated when the $F$ values were significant $(p<0.05)$.

\section{RESULTS}

Feed intake, milk yield and milk composition

To determine the first-limiting AAs in the milk production of Holstein dairy cows, the diets were formulated to exceed total AA requirements by $15 \%$ according to NRC [6]. The dry matter intake of the cows did not differ $(p>0.05$ ), and the values were 20.4,21.4,20.6, and $20.7 \mathrm{~kg} / \mathrm{d}$ for control, $4 \mathrm{AA}$, no-Met and no-Lys, respectively. Timothy hay was offered ad libitum, and the intake was numerically $(p=0.185)$ greater in cows infused with the 4AA compared with the others (Table 3 ).

The milk production of the lactating dairy cows that were infused with the mixture of lysine, methionine, isoleucine and valine by aqueous infusion into the jugular vein was numerically higher $(32.4 \mathrm{~kg} / \mathrm{d})$ than in the rest of the treatments, although there was no significant difference when compared with the control $(31.2 \mathrm{~kg} / \mathrm{d})$, no-Met $(31.3 \mathrm{~kg} / \mathrm{d})$, and no-Lys $(31.7 \mathrm{~kg} / \mathrm{d})$ treatment. NoMet had lower milk protein content $(p<0.05)$ and yield $(p<0.05)$, when compared with the 4AA and the no-Lys treatment $(p<0.05)$, and was similar to the control. As for lactose content, no-Met had a higher content (4.84\%) when compared with the other treatments $(p<0.05)$; however, there was no difference in lactose yield.

\section{Blood amino acids}

In terms of blood plasma AA concentrations, isoleucine and valine were lower in the control $(p<$ $0.05)$ than in the other treatments (Table 4). No-Met showed a lower $(p<0.05)$ methionine concentration in blood plasma, when compared with those that had methionine supplemented to their diets. Likewise, the diets without lysine supplements (i.e., control and no-Lys) showed a relatively

Table 3. Effects of intravenous infusions of amino acids (AA) on feed intake, and milk composition and production of Holstein dairy cows

\begin{tabular}{|c|c|c|c|c|c|c|}
\hline \multirow{2}{*}{ Item } & \multicolumn{4}{|c|}{ Treatment $^{1)}$} & \multirow{2}{*}{ SED } & \multirow{2}{*}{$p$-value } \\
\hline & Control & 4AA & no-Met & no-Lys & & \\
\hline \multicolumn{7}{|c|}{ Dry matter intake $(\mathrm{kg} / \mathrm{d})$} \\
\hline Concentrates & 12.1 & 12.1 & 12.1 & 12.1 & - & \\
\hline Corn silage & 2.5 & 2.5 & 2.5 & 2.5 & - & \\
\hline Alfalfa hay & 0.9 & 0.9 & 0.9 & 0.9 & - & \\
\hline Timothy hay & 4.9 & 5.9 & 5.1 & 5.2 & 0.42 & 0.185 \\
\hline Total & 20.4 & 21.4 & 20.6 & 20.7 & - & \\
\hline Milk yield (kg/d) & 31.2 & 32.4 & 31.3 & 31.7 & 0.64 & 0.284 \\
\hline Fat $(\mathrm{g} / \mathrm{kg})$ & 31.6 & 32.9 & 34.0 & 33.0 & 1.74 & 0.617 \\
\hline Fat $(\mathrm{g} / \mathrm{d})$ & 987 & 1,067 & 1,068 & 1,049 & 45.0 & 0.318 \\
\hline Protein $(\mathrm{g} / \mathrm{kg})$ & $29.3^{\mathrm{a}}$ & $30.8^{\mathrm{b}}$ & $29.1^{\mathrm{a}}$ & $30.7^{b}$ & 0.44 & 0.015 \\
\hline Protein $(g / d)$ & $913^{\mathrm{a}}$ & $997^{b}$ & $910^{\mathrm{a}}$ & $970^{\mathrm{b}}$ & 18.3 & 0.008 \\
\hline Lactose (g/kg) & $48.1^{b}$ & $48.0^{\mathrm{b}}$ & $48.4^{\mathrm{c}}$ & $47.6^{\mathrm{a}}$ & 0.11 & 0.003 \\
\hline Lactose $(\mathrm{g} / \mathrm{d})$ & 1,503 & 1,561 & 1,518 & 1,509 & 30.3 & 0.305 \\
\hline
\end{tabular}

${ }^{1)}$ Control, no infusion; 4AA, mixture of $6 \mathrm{~g} / \mathrm{d}$ methionine, $19.1 \mathrm{~g} / \mathrm{d}$ lysine, $13.8 \mathrm{~g} / \mathrm{d}$ isoleucine and $15.4 \mathrm{~g} / \mathrm{d}$ valine; no-Met, mixture without methionine; no-Lys, mixture without lysine.

${ }^{a-c}$ Means with different letters within a row differ at $p<0.05$.

SED, standard error of the differences. 
Table 4. Effects of intravenous infusions of amino acid on the concentrations ( $\mu \mathrm{mol} / \mathrm{L}$ ) of amino acids (AA) in blood plasma of Holstein dairy cows

\begin{tabular}{|c|c|c|c|c|c|c|}
\hline \multirow{2}{*}{ Item } & \multicolumn{4}{|c|}{ Treatment $^{1)}$} & \multirow{2}{*}{ SED } & \multirow{2}{*}{$p$-value } \\
\hline & Control & 4AA & no-Met & no-Lys & & \\
\hline \multicolumn{7}{|l|}{ Essential AA } \\
\hline Arginine & 92 & 92 & 89 & 80 & 9.8 & 0.601 \\
\hline Histidine & 65 & 58 & 65 & 63 & 6.0 & 0.591 \\
\hline Isoleucine & $111^{a}$ & $162^{a b}$ & $208^{\mathrm{b}}$ & $197^{b}$ & 26.4 & 0.038 \\
\hline Leucine & 151 & 140 & 158 & 143 & 17.4 & 0.737 \\
\hline Lysine & $81^{a}$ & $121^{\mathrm{ab}}$ & $162^{b}$ & $82^{\mathrm{a}}$ & 21.5 & 0.026 \\
\hline Methionine & $30^{\mathrm{a}}$ & $52^{\mathrm{ab}}$ & $29^{\mathrm{a}}$ & $68^{b}$ & 14.0 & 0.083 \\
\hline Phenylalanine & 49 & 44 & 51 & 46 & 5.7 & 0.681 \\
\hline Threonine & $215^{\mathrm{b}}$ & $197^{\mathrm{a}}$ & $186^{a}$ & $194^{\mathrm{a}}$ & 6.4 & 0.017 \\
\hline Valine & $209^{a}$ & $302^{b}$ & $367^{b}$ & $346^{\mathrm{b}}$ & 37.3 & 0.021 \\
\hline \multicolumn{7}{|l|}{ Non-essential AA } \\
\hline Alanine & 170 & 165 & 178 & 154 & 23.0 & 0.754 \\
\hline Aspartic acid & 12 & 10 & 14 & 13 & 3.2 & 0.626 \\
\hline Cysteine & 24 & 26 & 27 & 32 & 3.5 & 0.199 \\
\hline Glycine & 246 & 211 & 244 & 230 & 28.8 & 0.627 \\
\hline Glutamic acid & 126 & 130 & 144 & 144 & 17.1 & 0.649 \\
\hline Proline & 76 & 65 & 68 & 68 & 11.2 & 0.804 \\
\hline Serine & 74 & 64 & 69 & 69 & 9.4 & 0.556 \\
\hline Tyrosine & 49 & 39 & 42 & 42 & 5.5 & 0.335 \\
\hline
\end{tabular}

lower $(p<0.05)$ concentration in plasma, compared with 4AA and no-Met, although there was substantial variation between treatments (Table 4). In addition to the four AAs associated with supplemental treatments, there were no differences $(p>0.05)$ between the treatments, in terms of the individual AAs; however, threonine was significantly higher $(p<0.05)$ in cows that were offered the control diet, relative to the other treatments.

\section{DISCUSSION}

Dry matter intake in animals varies depending on the $\mathrm{N}$ level in the diets. The levels of essential AA and crude protein in the diets significantly affect dry matter intake. These are also affected when there is a large difference between the AA level in feed and the amount of AA required by the animal [12,23-26]. It is notable that a significant proportion of corn grain was used as a source of feed ingredient in this study. However, the composition of essential AAs in the crude protein of corn grain is known to be unbalanced, since it is low in lysine [27,28]. Therefore, dairy diets formulated with high a level of corn grain (a typical feeding regime in Korea) do not supply sufficient lysine to high-producing dairy cows. It is also understood that corn- and soybean-rich diets are not satisfactory for supplying methionine to high-producing dairy cows [29,30]. Even in a monogastric animal, such as rats, when such cereal grains were fed to them, there was a remarkable decrease in feed intake and weight gain, as well as a lowering of the efficiency of AA utilization in the body [31]. When using feeds that have a low crude protein content, or that have an unbalanced AA compo- 
sition, it is possible to improve feed intake, weight gain, and the efficiency of AA utilization in the body of the animal by supplementing the deficient essential AAs [32].

In the present study, with an increased supply of lysine and/or methionine, the dairy cow's productivity seemed to improve. The response in the milk production of dairy cows to the supply of lysine and methionine is usually observed in the early lactation period rather than in the mid-lactation or late-lactation period [33]. Literature has shown that the increased supply of lysine and methionine to dairy cows, following the highest lactation period, induced a more sensitive response in milk yield than in milk protein content [34-36]. Nimrick et al. [37] reported that, when urea was supplied as the only source of $\mathrm{N}$, the experimental animals exhibited a deficiency in lysine, methionine, and threonine and that the infusion of lysine and methionine into the abomasum caused an improvement in the usability of protein in dairy cow, sheep, and deer [38-41].

Accordingly, the results of the present study showed that milk protein content and milk yield varied depending on the supply of either lysine or methionine and were independent of the supply of either isoleucine or valine. However, the response seemed more pronounced when methionine was supplemented in the diet (Table 3). This may indicate that methionine is more limiting than that of lysine in this study, where the diets were mainly formulated with corn grain and soybean meal. Our result is in agreement with Socha et al. [42], who reported that cows were responded favorably to additional rumen-protected methionine compared with rumen-protected Lys. Further study by Patton [11] proved the effect of supplemental rumen-protected methionine in terms of milk protein yield. We did not expect methionine to be the first-limiting because corn was the primary energy sourced in the experimental diet. However, since NRC [6] concluded that lysing and methionine are the two most limiting AAs in dairy diets, a diet formulation for dairy cows may be an essential factor to decide which AA is more limiting than the other. Overton et al. [43] reported that, following supplementation of rumen-protected methionine in the diet of dairy cows, the plasma methionine concentration increased; however, there was a decrease in the plasma histidine concentration. In addition, the plasma concentrations of arginine and lysine, following rumen-protected methionine supplementation, were lower than those of the plasma from the cows offered with the non-treated diet. This indicates that methionine may have an impact on utilization of other AAs. Overton et al. [43] further reported that there was a diet $\times$ methionine interaction, where the concentrations of phenylalanine, threonine, and cysteine in plasma differed depending on their basal diets (i.e., ground shelled corn vs. corn gluten feed). In this study, the concentration of threonine in plasma from the control diet was higher than those of 4AA, no-Met and no-Lys, and this may indicate that methionine (and/or lysine) affects the metabolism of other AAs for example, the absorption and utilization of other AAs, resulting in a change in the concentration of other plasma AA.

\section{CONCLUSION}

With a typical feeding regime where the level of concentrate was relatively high, capable of producing well over $9,000 \mathrm{~kg}$ of milk per annum, Holstein dairy cows received intravenously a mixture of AAs, such as methionine, lysine, isoleucine, and valine, or the same mixture without either methionine or lysine. The cows that were fed with the control diet did not receive an infusion. The composition of AA in blood plasma was altered with the mixed AAs, with or without either methionine or lysine. These changes in blood plasma were reflected in milk protein content, although the changes were marginal. Nevertheless, the results of this study may provide some insight into the AA requirements of dairy cows in Korea, which are offered diets with corn grain and soybean meal mostly imported from other countries. Further studies are needed to identify AA requirements in 
various dietary regimes, and this is very important for animals fed on total mixed rations where the feed ingredients change more rapidly.

\section{REFERENCES}

1. FAO [Food and Agriculture Organisation of the United Nations]. Livestock's long shadow Environmental issues and options. Rome: FAO; 2006.

2. Vérité R, Michalet-Doreau B, Chapoutot $\mathrm{P}$, Peyraud JL, Poncet C. Révision du systém des protéines digestibles dans l'intesitn (PDI). Bull Tech CRZVTheix INRA. 1987;70:19-34.

3. Rulquin H, Delaby L. Effects of the energy balance of dairy cows on lactational responses to rumen-protected methionine.J Dairy Sci. 1997;80:2513-22.

4. Fox DG, Sniffen CJ, O'Connor JD, Russell JB, Van Soest PJ. A net carbohydrate and protein system for evaluating cattle diets: III. cattle requirements and diet adequacy. J Anim Sci. 1992;70:3578-96.

5. Lanzas C, Sniffen CJ, Seo S, Tedeschi LO, Fox DG. A revised CNCPS feed carbohydrate fractionation scheme for formulating rations for ruminants. Anim Feed Sci Technol. 2007;136:167-90.

6. National Research Council. Nutrient requirements of dairy cattle. 7th ed. Washington, DC: National Academy Press; 2001.

7. Rulquin $\mathrm{H}$, Graulet B, Delaby L, Robert JC. Effect of different forms of methionine on lactational performance of dairy cows.J Dairy Sci. 2006;89:4387-94.

8. Armentano LE, Bertics SJ, Ducharme GA. Response of lactating cows to methionine or methionine plus lysine added to high protein diets based on alfalfa and heated soybeans. J Dairy Sci. 1997;80:1194-9.

9. Robinson PH, Swanepoel N, Evans E. Effects of feeding a ruminally protected lysine product, with or without isoleucine, valine and histidine, to lactating dairy cows on their productive performance and plasma amino acid profiles. Anim Feed Sci Technol. 2010;161:75-84.

10. Derrig RG, Clark JH, Davis CL. Effect of abomasal infusion of sodium caseinate on milk yield, nitrogen utilization and amino acid nutrition of the dairy cow.J Nutr. 1974;104:151-9.

11. Patton RA. Effect of rumen-protected methionine on feed intake, milk production, true milk protein concentration, and true milk protein yield, and the factors that influence these effects: a meta-analysis. J Dairy Sci. 2010;93:2105-18.

12. Nursoy H, Ronquillo MG, Faciola AP, Broderick GA. Lactation response to soybean meal and rumen-protected methionine supplementation of corn silage-based diets. J Dairy Sci. 2018;101:2084-95.

13. Rogers GL, Bryant AM, Mcleay LM. Silage and dairy cow production: III. abomasal infusions of casein, methionine, and glucose, and milk-yield and composition. N Z J Agric Res. 1979;22:533-41.

14. Kim CH, Choung JJ, Chamberlain DG. Determination of the first-limiting amino acid for milk production in dairy cows consuming a diet of grass silage and a cereal-based supplement containing feather meal. J Sci Food Agric. 1999;79:1703-8.

15. Vanhatalo A, Huhtanen P, Toivonen V, Varvikko T. Response of dairy cows fed grass silage diets to abomasal infusions of histidine alone or in combinations with methionine and lysine.J Dairy Sci. 1999;82:2674-85.

16. Huhtanen P, Vanhatalo A, Varvikko T. Effects of abomasal infusions of histidine, glucose, and leucine on milk production and plasma metabolites of dairy cows fed grass silage diets. J Dairy Sci. 2002;85:204-16. 
17. Papas AM, Vicini JL, Clark JH, Peirce-Sandner S. Effect of rumen-protected methionine on plasma-free amino-acids and production by dairy cows.J Nutr. 1984;114:2221-7.

18. Rogers JA, Krishnamoorthy U, Sniffen CJ. Plasma amino acids and milk protein production by cows fed rumen-protected methionine and lysine.J Dairy Sci. 1987;70:789-98.

19. Park JK, Lim DH, Kim SB, Ki KS, Lee HJ, Kwon EG, et al. Effects of partial replacement of corn grain and soybean meal with agricultural by-product feeds on in vitro rumen fermentation characteristics and optimum levels of mixing ratio. J Anim Sci Technol. 2011;53:441-50.

20. AOAC [Association of Official Analytical Chemists]. Official methods of analysis of AOAC International. 16th ed. Washington, DC: AOAC; 1995.

21. Van Soest PJ, Robertson JB, Lewis BA. Methods for dietary fiber, neutral detergent fiber, and nonstarch polysaccharides in relation to animal nutrition.J Dairy Sci. 1991;74:3583-97.

22. Payne RW, Murray DA, Harding SA, Baird DB, Soutar DM. GenStat for Windows 9th edition, introduction. Hemel Hempstead, UK: VSN International; 2006.

23. Meliza LL, Leung PMB, Rogers QR. Effect of anterior prepyriform and medial amygdaloid-lesions on acquisition of taste-avoidance and response to dietary amino-acid imbalance. Physiol Behav. 1981;26:1031-5.

24. Gietzen DW, Leung PMB, Rogers QR. Dietary amino acid imbalance and neurochemical changes in three hypothalamic areas. Physiol Behav. 1989;46:503-11.

25. Jiang JC, Gietzen DW. Anorectic response to amino acid imbalance: a selective serotonin3 effect? Pharmacol Biochem Behav. 1994;47:59-63.

26. Giallongo F, Harper MT, Oh J, Lopes JC, Lapierre H, Patton RA, et al. Effects of rumen-protected methionine, lysine, and histidine on lactation performance of dairy cows. J Dairy Sci. 2016;99:4437-52.

27. Coleman CE, Larkins BA. The prolamins of maize. In: Shewry PR, Casey R, editors. Seed proteins. Dordrecht: Springer; 1999.p. 109-39.

28. Kriz AL. Enhancement of amino acid availability in corn grain. In: Kriz AL, Larkins BA, editors. Molecular genetic approaches to maize improvement. Berlin Heidelberg: Springer-Verlag; 2009. p. 79-89.

29. Schwab CG, Bozak CK, Whitehouse NL, Mesbah MMA. Amino acid limitation and flow to duodenum at four stages of lactation. 1. sequence of lysine and methionine limitation. J Dairy Sci. 1992;75:3486-502.

30. Weiss WP. Effects of feeding diets composed of corn silage and a corn milling product with and without supplemental lysine and methionine to dairy cows.J Dairy Sci. 2019;102:2075-84.

31. Kim C, Tanaka H, Ogura M. Metabolism of lysine, threonine, and leucine in growing rats on gluten or zein diets at various dietary protein levels. Biosci Biotechnol Biochem. 1996;60:15805.

32. Broderick GA, Stevenson MJ, Patton RA, Lobos NE, Colmenero JJO. Effect of supplementing rumen-protected methionine on production and nitrogen excretion in lactating dairy cows. J Dairy Sci. 2008;91:1092-102.

33. Sloan BK. Developments in amino acid nutrition of dairy cows. Recent Adv Anim Nutr. 1997;167-98.

34. Sloan BK, Garthwaite BD, Schwab CG. Practical formulation of dairy cow diets for digestible amino acids to improve nitrogen efficiency and the bottom line. In: Proceedings - Cornell Nutrition Conference for Feed Manufacturers; 1998; Ithaca, NY.

35. Lee C, Hristov AN, Heyler KS, Cassidy TW, Lapierre H, Varga GA, et al. Effects of metabolizable protein supply and amino acid supplementation on nitrogen utilization, milk production, and ammonia emissions from manure in dairy cows.J Dairy Sci. 2012;95:5253-68. 
36. Awawdeh MS. Rumen-protected methionine and lysine: effects on milk production and plasma amino acids of dairy cows with reference to metabolisable protein status. J Dairy Res. 2016;83:151-5.

37. Nimrick K, Hatfield EE, Kaminski J, Owens FN. Qualitative assessment of supplemental amino acid needs for growing lambs fed urea as the sole nitrogen source. J Nutr. 1970;100:1293300.

38. Fisher LJ. Response of lactating cows to the intravenous infusion of amno acids. Can J Anim Sci. 1972;52:377-84.

39. Doyle PT, Bird PR. The influence of dietary supplements of DL-methionine on the growth rate of wool. Aust J Agric Res. 1975;26:337-42.

40. Schelling GT, Chandler JE, Scott GC. Postruminal supplemental methionine infusion to sheep fed high quality diets.J Anim Sci. 1973;37:1034-9.

41. Huang J, Sun WL, Li CY, Liu HL, Zhang TT, Bao K, et al. Effects of DL-methionine supplement on growth performance and amino acid digestion and plasma concentrations in sika deer calves (Cervus nippon). Anim Prod Sci. 2016;56:1002-7.

42. Socha MT, Putnam DE, Garthwaite BD, Whitehouse NL, Kierstead NA, Schwab CG, et al. Improving intestinal amino acid supply of pre- and postpartum dairy cows with rumen-protected methionine and lysine.J Dairy Sci. 2005;88:1113-26.

43. Overton TR, Emmert LS, Clark JH. Effects of source of carbohydrate and protein and rumen-protected methionine on performance of cows.J Dairy Sci. 1998;81:221-8. 